\title{
Solidão e exílio: um olhar sobre as personagens femininas em Uma certa felicidade, de Sonia Coutinho
}

Luciana Asadczuk ${ }^{1}$

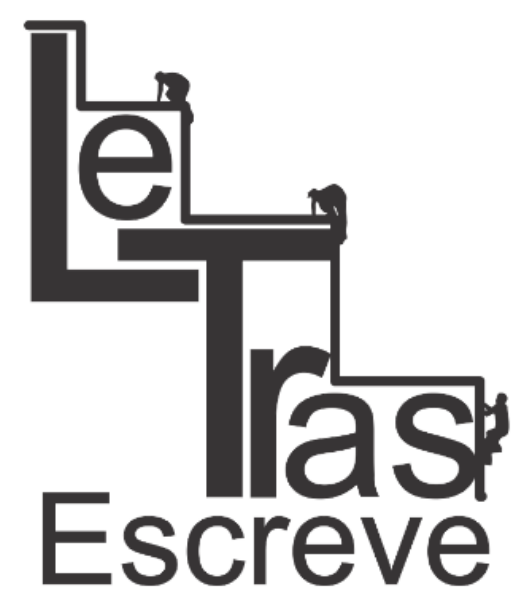

(ISSN 2238-8060)
Resumo: Sonia Coutinho, uma das mais influentes escritoras da contemporaneidade, publicou diversas obras retratando mulheres que vivem os desafios da transição das normas tradicionais para a modernidade e se sentem exiladas de seu lugar de origem, bem como deslocadas em sua nova morada. A maioria de suas personagens tem origem em Salvador, na Bahia, e se deslocam até o Rio de Janeiro. Estas, na maioria das vezes, são divorciadas ou então simplesmente "fogem" das normas impostas pela família e pela sociedade para buscar seus sonhos longe da cidade provinciana e viverem livres. Na maioria das vezes, não conseguem mais ter contato com a família e vivem na solidão, exiladas, com saudade do passado, mas ao mesmo tempo, sem vontade e sem a possibilidade de voltar. Partindo desta problemática, este artigo tem como objetivo analisar as personagens que saíram de suas origens (família tradicional e cidade provinciana) para viver no Rio, mas enfrentam problemas de solidão e saudade. Serão analisadas as personagens femininas principais dos contos Uma certa felicidade, Amigas (I), ou a liberdade secreta e Amigas (II), ou aconteceu no Jardim Botânico?. Estes fazem parte da obra intitulada Uma certa felicidade, publicada em 1976 e reeditada em 1994, de Sonia Coutinho.

Palavras-chave: Solidão; Exílio; Sonia Coutinho.

Abstract: Sonia Coutinho, one of the most influents writer of the contemporary times, has published several works depicting women living the transition challenges of the traditional standards to the modernity and feel exiled from your origin place, as well as, displaced in your new location. Most of the characters have your origin in Salvador, Bahia, and they move to Rio de Janeiro. These, many times, are divorced or just "flee" from the imposed standards by the family and the society to get your dreams away from provincial city and to have a free life. Sometimes, they can't have contact with the family, living in solitude, exiled, yearning for the past, but at the same time, unwilling and unable to return. From this issue, this paper has the aim to analyze the characters that leave their origins (traditional family and provincial city) to live in Rio, but facing problems of loneliness and longing. Will be analyzed the principal female characters from the tales Uma Certa Felicidade, Amigas (I) or A Liberdade secreta and Amigas (II) or Aconteceu no Jardim Botânico? These are part of the work

${ }^{1}$ Licenciada em Letras Português/Francês e Respectivas Literaturas pela UEPG. E-mail: luciana.asdk@gmail.com Artigo apresentado com requisito de aprovação na disciplina "Literatura, Subjetividade e Exílio" do programa de Mestrado em Linguagem, Identidade e Subjetividade da Universidade Estadual de Ponta Grossa (UEPG), ministrada pela Prof ${ }^{a}$. Dr ${ }^{a}$ Keli Cristina Pacheco.

https://periodicos.unifap.br/index.php/letras

Macapá, v. 6, n. I, Io semestre, 2016. 


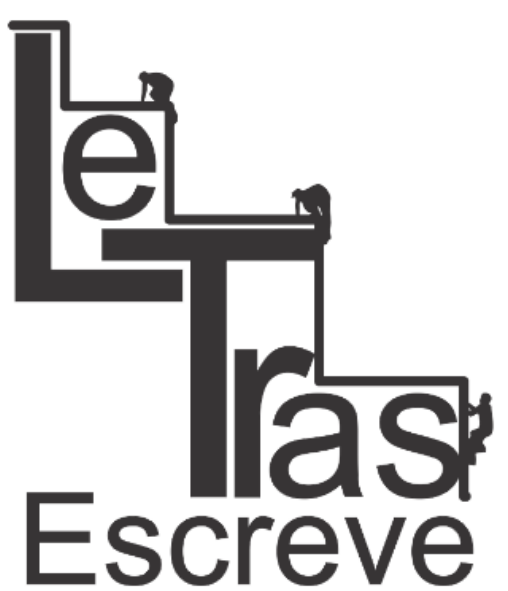

(ISSN 2238-8060) entitled Uma certa felicidade, published in 1976 and reissued in 1994, of Sonia Coutinho.

Keywords: Loneliness; Exile; Sonia Coutinho;

Contista, tradutora e jornalista, Sonia Coutinho é natural de Itabuna (Bahia) e mudou-se para o Rio de Janeiro em 1968, onde faleceu aos 74 anos de idade, em 2013. Escritora premiada várias vezes, recebeu o prêmio Jabuti em 1979 pela obra Os venenos de Lucrécia e, em 1999, pelo livro Os seios de Pandora. A autora vinha se destacando desde os anos 60, quando lançou seu primeiro livro, O herói inútil, em 1964. Além do Jabuti, foi premiada também, em 2006, com o Prêmio Clarice Lispector, da Biblioteca Nacional, pelo volume de contos intitulado Ovelha negra e amiga loura. "Outros livros de destaque, de sua autoria, são Uma certa felicidade, Mil olhos de uma rosa, O caso Alice e O jogo de Ifá. Sonia teve livros e contos lançados nos Estados Unidos, França e Alemanha" (SANTANA, 2014, p.1). Suas obras, em geral, abordam a questão da mulher em transição. Aquela que saiu das imposições de um patriarcalismo já ultrapassado e tenta reerguer sua vida longe de seu local de origem. Mas, para isso, precisa enfrentar um novo mundo de descobertas e, desta forma, passa a viver na solidão. Segundo Cesar (2008), "é uma mulher em transformação. Ela está definindo sua personalidade e precisa enfrentar diversos conflitos com os quais tem de conviver nesta busca por seu espaço no mundo e pela valorização de quem é como ser humano" (p. 141). Suas personagens, na maioria das vezes, são da cidade de Solinas, cidade fictícia, na Bahia, e vivem no Rio de Janeiro. Algumas continuam em Solinas, outras fugiram para não mais voltar, devido às normas conservadoras que ainda resistem na pequena cidade baiana. De acordo com Cesar (2008),

A obra de Sonia permite igualmente uma leitura simbólica, na medida em que a cidade de Solinas, origem da maior parte das personagens, pode ser vista como representante da tradição, em contraponto ao Rio de Janeiro, como um espaço de liberdade em relação a padrões socialmente impostos. Assim, é 
frequente a existência de personagens que tentam desligar-se do passado e das tradições, porém sofrem as consequências de sua escolha. Este conflito se refere, não apenas aos padrões impostos pela sociedade tradicional, mas também a própria dificuldade que tem o ser humano de romper com o passado, mantendo uma dívida a resgatar com suas raízes. [...] é necessário um longo processo reflexivo para reconstruir o próprio $\mathrm{Eu}$ e a sua relação com o mundo, a partir destas modificações que, sem dúvida, interferem na maneira como cada um vê a própria identidade (p. 141).

As personagens femininas de Sonia representam a mulher do século $X X$ e $X X I$ e suas dificuldades de mostrar à sociedade que podem sim, viver sozinhas, sem a necessidade de se casar e ter filhos. Ainda de acordo com Cesar (2008),

nessas compilações, os contos estão carregados de sentimentos, impressões, relatos de traumas de infância, julgamentos sociais sobre as mais diversas atitudes tomadas ao longo da vida das mulheres. O tipo feminino retratado tem uma série de características comuns: são mulheres de uma geração posterior à década de 70 , que sofrem muito com as dificuldades de ser uma mulher independente e moderna numa sociedade machista (p.134).

Assim como suas personagens, que se reinventam tentando superar o novo mundo pela frente, a linguagem utilizada pela autora também tem suas características criativas. Sua maneira de narrar e contar o cotidiano das personagens é como um jogo de fragmentos que exige atenção do leitor para ligar os fatos. Segundo Patrício (1999) apud Silva (2010),

a linguagem dos romances de Sonia Coutinho é labiríntica, constitui-se num intricado jogo de fragmentos que exige uma performance diferenciada de leitura. Essa técnica resulta em um fluxo irregular das informações, com avanços, recuos, repetições, retomadas, reiterações e omissões que deixam margem para a intervenção do leitor (p.54).

Estas irregularidades na escrita de Sonia fazem com que o leitor atento perceba que a maioria de sua obra parece falar de uma mesma personagem, de uma mesma mulher, com desfechos semelhantes em alguns casos e diferentes em outros. Alguns 


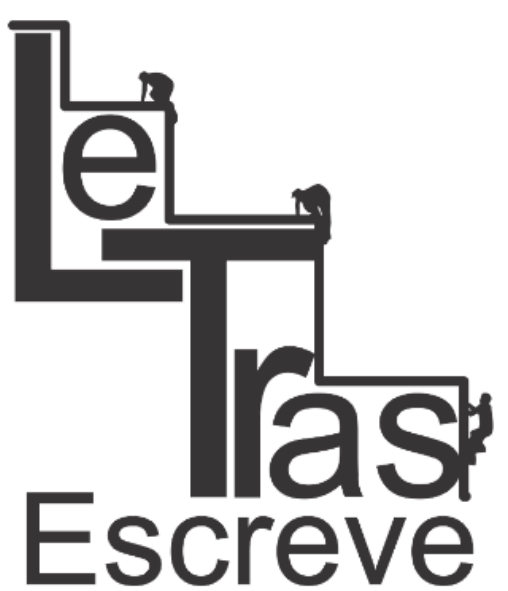

(ISSN 2238-8060)

críticos $^{2}$ destacam-na como uma das mais importantes escritoras da moderna literatura brasileira. Seu modo de pensar a mulher é inovador em uma época onde pouco se fala em transgredir as normas impostas pela sociedade ainda crente nos costumes deixados pelo patriarcalismo.

Apesar do sofrimento para se adaptarem no Rio, as personagens de Sonia, em alguns casos, apresentam-se felizes com a nova vida, mas com uma restrição: não voltar mais à sua terra natal. Isso porque há um ressentimento por parte da família que deixaram em Solinas. Sendo assim, pode-se afirmar que as mesmas vivem exiladas no Rio. É o caso do livro Uma certa felicidade, publicado em sua primeira edição em 1979 e reeditado em 1994. Esta obra é composta por nove contos e traz claramente a situação de personagens que nasceram em Solinas, foram morar no Rio e não podem voltar à cidade natal devido à não aceitação da família.

Neste trabalho focalizarei os contos Uma certa felicidade, Amigas (I), ou a liberdade secreta e Amigas (II), ou aconteceu em Copacabana?. São contos que trazem personagens femininas que, por algum motivo, tiveram que deixar sua cidade natal, Solinas, e foram viver no Rio. Portanto, vivem com o sentimento de não poder voltar e isso Ihes traz solidão. Sendo assim, vivem exiladas de sua família e sua cidade natal. Demonstram, principalmente no conto Uma certa Felicidade, muita saudade da cidade que deixaram, descrevendo sempre o clima e as imagens que lembram dela.

\section{Exílio como alternativa de fuga}

Uma certa felicidade é o primeiro conto da coletânea que também leva o mesmo nome. O conto é narrado por uma voz em

\footnotetext{
2 Aqui cito como exemplo Adonias Filho, crítico literário, ensaísta, jornalista, etc., que deixou suas observações sobre a obra de Sonia Coutinho, mais especificamente na orelha do livro Nascimento de uma Mulher, publicado em 1970 pela autora. Nesta obra, Adonias a coloca na moderna ficção brasileira, justificando esta colocação.
}

https://periodicos.unifap.br/index.php/letras

Macapá, v. 6, n. I, Io semestre, 2016. 
primeira pessoa sob o ponto de vista da personagem protagonista, a qual não apresenta um nome próprio, nem mesmo um apelido.

A narradora intradiegética, através da homodiegese, vagueia do presente ao passado e vice-versa. Trata-se de uma narrativa de linguagem confusa, com muitas lembranças que surgem de forma fragmentada e inconstante. Ao destacar as lembranças de acontecimentos passados, de quando morava em Solinas, a narradora demonstra saudade ao falar da cidade e das pessoas que deixou para trás. Vivendo no Rio de Janeiro, divide um apartamento com a amiga Marcia, para a qual conta parte de sua história, do noivo que tinha, da cidade em que viveu e dos problemas com a família.

A narradora destaca a admiração da personagem pela cidade:

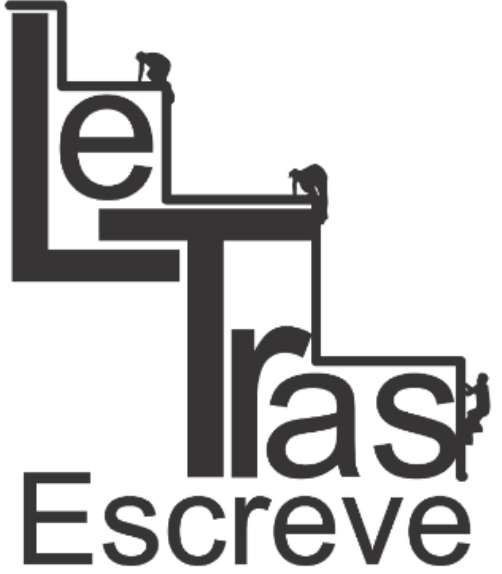

(ISSN 2238-8060)

Engraçado é que não era bem de nós dois que eu falava, mas da Cidade, como se tudo só tivesse podido acontecer ali, com aquele ruído de mar, os faróis acesos ao entardecer e o som rouco dos búzios dos grandes barcos passando lentamente, gigantescas velas infladas (COUTINHO, 1994, p.9-10).

A saudade do clima da cidade enche-a de lembranças e assim, a narradora as descreve:

Os crepúsculos de verão na Cidade têm um sabor de ideia platônica ou verdade eterna. Vastidão de espaços abertos sob o vento, quilômetros de praias desertas, com coqueirais, e as cores que se erguem irisadas no horizonte: verde-azulado, rosa, lilás, a luminosidade vermelho-dourada que o sol imenso irradia.

O verão no auge, coberta por uma vaga poeira dourada e todos os tons quentes, a fruta aberta, a polpa, a Cidade. Com seu céu sem limites, o maior céu azul-veludo do mundo, a pobre riquíssima cidade, coberta de ouro e opalas (COUTINHO, 1994, p.11).

Ao descrever a beleza que o clima da cidade interiorana proporcionava, a narradora lembra-se de como era sua casa e a compara, indiretamente, com o apartamento em que vive no Rio. 
A luz devoradora, quente/morna, que precede o entardecer, atravessa as vidraças do salão, reverbera nas paredes amarelas, enche de uma claridade ofuscante esta antiga casa de dois andares onde vagueio. Os dias, como um deserto. Vaguear do primeiro para o segundo piso, subindo esta escada, no qual fico, estirada na cama, horas e horas a imaginar [...] (COUTINHO, 1994, p.11)

Este apartamento em Copacabana é a coisa mais diferente de uma árvore que se pode imaginar. Quatro paredes, quartinho pegado à sala, através da janela a visão de mil outras, como reflexo em espelho. No começo, eu me encolhia na cama, pensava que estava com as pernas de fora e alguém podia espiar, imaginava um milhão de olhos a vigiar de luneta, do outro lado (COUTINHO, 1994, p.12).

Esta descrição faz lembrar a Canção do Exílio, de Gonçalves Dias, onde o eu-lírico expressa, através dos versos, a falta que sente de sua terra natal:

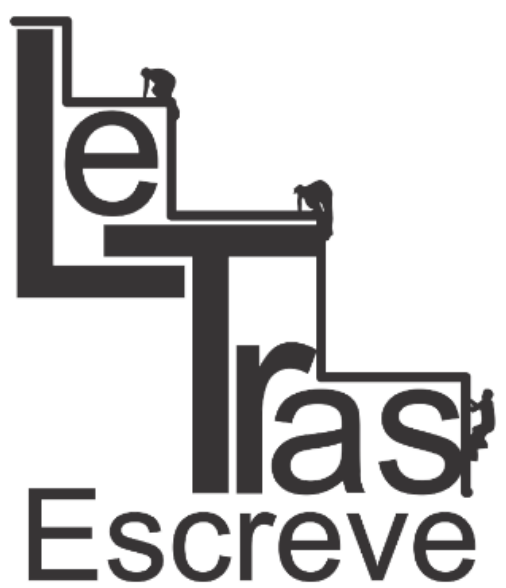

(ISSN 2238-8060)

Minha terra tem palmeiras

Onde canta o sabiá

As aves que aqui gorjeiam,

Não gorjeiam como lá.

Não permita Deus que eu morra,

Sem que volte para lá;

Sem que desfrute os primores

Que não encontro por cá;

Sem qu'inda aviste as palmeiras,

Onde canta o Sabiá ${ }^{3}$.

Assim também, a personagem deste conto, demonstra não se sentir bem ao morar no Rio lembrando-se da sua cidade natal. $O$ poema de Gonçalves Dias fala de um exilado de sua terra natal, mas um exilado de seu país, já o conto Uma certa felicidade fala das lembranças de uma personagem que deixou sua cidade baiana e foi morar no Rio de Janeiro, dentro do próprio país, mas a saudade que sente é a mesma. A diferença é que, neste caso, a personagem se exila por vontade própria, apenas impulsionada pela situação em que vivia com a família. O motivo pela qual a personagem deixa a cidade é a busca pela liberdade e a "fuga" das normas impostas pela

${ }^{3}$ DIAS, Gonçalves. Canção do Exílio. Primeiros cantos (1847).

https://periodicos.unifap.br/index.php/letras

Macapá, v. 6, n. I, Io semestre, 2016. 


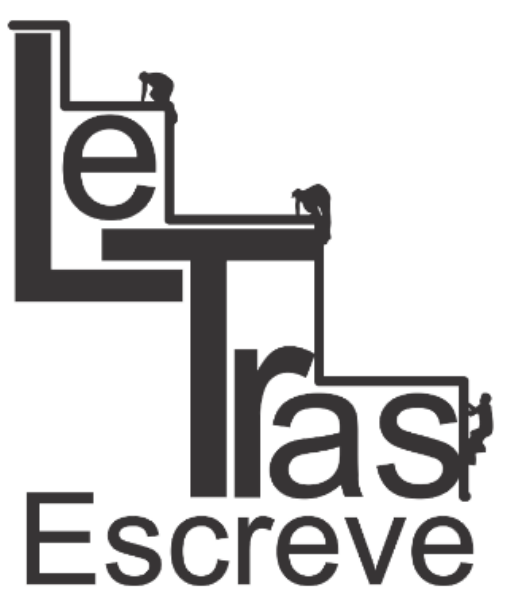

(ISSN 2238-8060) família tradicional. Ao se dar conta de que se se casasse com Irineu (seu noivo) teria de morar na Cidade Solinas e seguir uma vida de casada, dependente do marido, assim como sua mãe, decide fugir com um homem pelo qual se apaixonou. Naquela época, a das lembranças da personagem, os costumes eram mais rígidos. Uma vez casada, deveria viver para sempre com o mesmo homem e não era esse o destino que ela almejava:

Não sei se vocês sabem como é que a gente vivia lá na Cidade, àquele tempo. As famílias dentro de casa. $O$ pai sempre com o mesmo emprego, a vida toda. A mãe que se sacrificou pelos filhos. O casamento que não deu certo - nunca dava. Não podia dar e a gente nem chegava direito a saber como pode ser a relação de um homem com uma mulher, todo mundo fazendo tanta força para esconder. Separar, como? Não dava para separar, mulheres que nunca trabalharam fora de casa. Então, aguentávamos e ficávamos o tempo todo e o tempo passava. Se a gente foi bonita, um dia ia ficando mais velha e mais feia e havia a religião e a família, às quais a gente se prendia (COUTINHO, 1994, p.25).

A família e a religião tinham grande força na manutenção dos casamentos naquela cidade. A personagem ao ver que deveria seguir o mesmo caminho, foge de casa, deixando a família "desonrada". Em uma de suas lembranças, a personagem descreve uma conversa que teve com uma amiga que continuou morando em Solinas, sua cidade. A amiga questiona-a sobre a reação de sua família com a mudança ao Rio.

- e sua família, como é que reagiu à sua vinda, à nova vida?, ela perguntou, de improviso.

- da pior maneira possível. Nunca mais me escreveram, continuam sem querer me ver, meu pai considera-se "desonrado". Parece incrível, mas essas coisas ainda acontecem.

- você nunca pensa em voltar?

- não seria possível voltar (COUTINHO, 1994, p. 39).

Nesta passagem, pode-se perceber que a personagem encontra-se exilada, uma vez que não poderá voltar à sua cidade, devido à má aceitação por parte de seus pais sobre seu

https://periodicos.unifap.br/index.php/letras

Macapá, v. 6, n. I, Io semestre, 2016. 


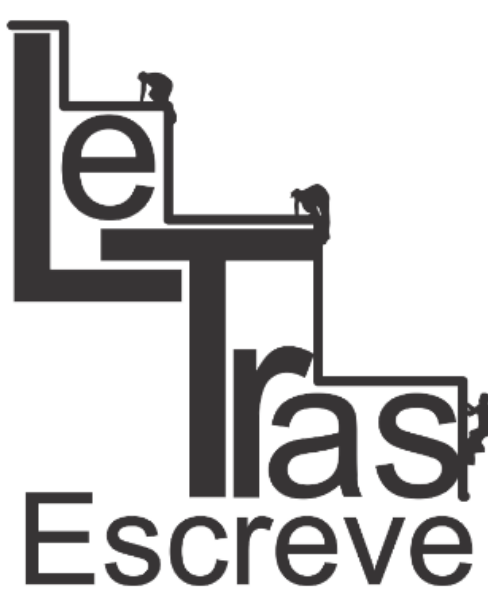

(ISSN 2238-8060) comportamento. Nesse sentido, pode-se perceber um exílio não no sentido de expulsão, uma vez que a personagem foi ao Rio por conta própria, mas no sentido de não poder retornar à sua cidade natal.

Edward Said (2003) acredita que o exílio "é uma fratura incurável entre um ser humano e um lugar natal, entre o eu e seu verdadeiro lar: sua tristeza essencial jamais pode ser superada" (p.46). Para ele, "o exílio é uma solidão vivida fora do grupo: a privação sentida por não estar com os outros na habitação comunal" (p. 50). É o que sente a personagem de Uma certa felicidade, ao não poder voltar ao seu grupo, ou seja, à sua família, seu local de origem. Sendo assim, este seria o lado negativo do exílio, a impossibilidade de retorno, a falta. "Os exilados estão separados das raízes, da terra natal, do passado" (SAID, 2003, p.50). Trata-se de um exílio sem retorno, na concepção de Said.

Esta forma de exílio também está presente nos contos Amigas (I), ou a liberdade secreta e Amigas (II), ou aconteceu o Jardim Botânico?. Estes também são contos da mesma coletânea Uma certa felicidade, e apresentam em suas narrativas situações semelhantes ao primeiro conto aqui analisado. As duas narrativas tem como personagem principal uma mulher que vive no Rio de Janeiro e recebe a visita de sua amiga, que ainda vive em Solinas, cidade onde a primeira também viveu. Os contos são narrados em primeira pessoa sob o ponto de vista da personagem que vive no Rio.

sentadas, nós duas, neste bar deserto em Copacabana, segunda-feira de tarde, espio o rosto de minha amiga, que o tempo só ligeiramente machucou (lá se foram cinco anos), [...] diante do que volto a manifestar, agradecida, a minha alegria (tinha pedido, em inúmeras cartas, para ela vir) - finalmente terei com quem falar, só consigo me comunicar de verdade com vocês de lá, o relacionamento entre as pessoas aqui tão frio e diferente, (COUTINHO, 1994, p.89, Amigas (I)). 
Ao declarar a alegria que sente ao reencontrar a amiga, a personagem demonstra o quanto se sente sozinha morando no Rio. O relacionamento dali não é como o de sua terra natal. É possível notar aqui o quanto a personagem sente-se exilada de tudo, até mesmo de relacionar-se com as pessoas. Mas o motivo pela qual ela se isolou fica claro no próximo fragmento:

agora diz dos meus pais, que a escolheram emissária do pedido: querem notícias minhas com maior regularidade, ao que respondo, a voz idiotamente embargada (e ainda!) - não me amavam, ou, se amavam, não era a mim que amavam (ó eterna menininha feiosa/esquisitinha/ magricela, a que nunca acreditou em Papai Noel, a que se masturbava escondida pelos cantos), (COUTINHO, 1994, p.91-92, Amigas (I)).

$\mathrm{O}$ isolamento da personagem se deu, como se pode perceber

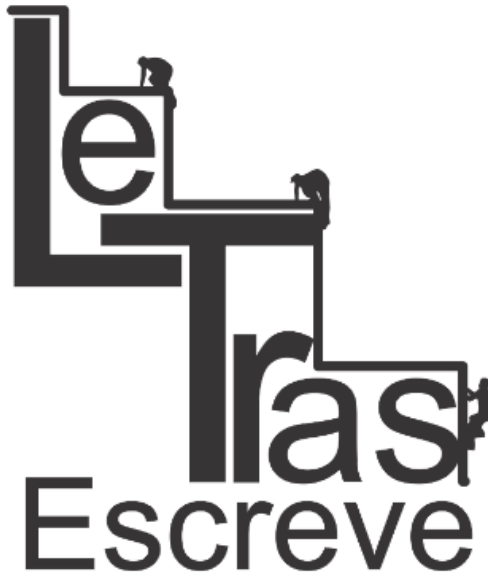

(ISSN 2238-8060) aqui, devido ao mau tratamento que recebia dos pais. Isso talvez devido aos costumes daquela cidade, naquela época, onde mulheres eram menosprezadas na família quando se recusavam a se casar e seguir os costumes dali. A amiga tenta entender o porquê de a personagem ter deixado a cidade: "o atendimento à suplica que leio nos olhos da antiga amiga: você deixou tanta coisa para trás, desprezou convenções, partiu sem nada explicar, só eu acreditei entender, tanto havíamos conversado, agora é preciso que me transmita o legado (COUTINHO, 1994, p.92, Amigas (I)). A amiga insiste em saber o que a outra conquistou ao ir embora da cidade, mas ela continua a disfarçar falando de outras coisas:

Portanto me disponho ao supremo esforço, neste momento lhe digo: o mais nobre que tenho a oferecer, aquilo que, num Juízo Final, exibiria ao Criador, como justificativa para omissões tão graves (a arma que não empunhei contra a injustiça, o filho que não tive, o homem a quem não me prendi, ou não consegui me prender, a falta de compaixão pelos mais próximos, no cumprimento do obstinado sacerdócio), são uns pequenos objetos que andei fabricando, em escassos momentos roubados à lida diária (COUTINHO, 1994, p. 94, Amigas (I)). 
Nesta passagem, fica claro o motivo pela qual a personagem vive sozinha no Rio e, diante das circunstâncias, não pretende voltar. No conto Amigas (II), a situação é parecida. A impressão que se tem é de que são as mesmas personagens do primeiro conto (Amigas (I)). O conto é narrado em terceira pessoa e fala do encontro de duas amigas. Uma mora no Rio e a outra na cidade onde a primeira nasceu.

Eram tão amigas, antes de ela vir embora. Por isso, a outra lhe conta sua vida com uma intimidade que poderia parecer insólita, nem sequer se escreviam. Pelo que trocaram mil desculpas, quando, num golpe casual do olhar, identificou-a, ontem, entre as mil faces do meio-dia na Avenida Copacabana, ao lado do marido advogado, de férias no Rio (COUTINHO, 1994, p. 99, (Amigas (II)).

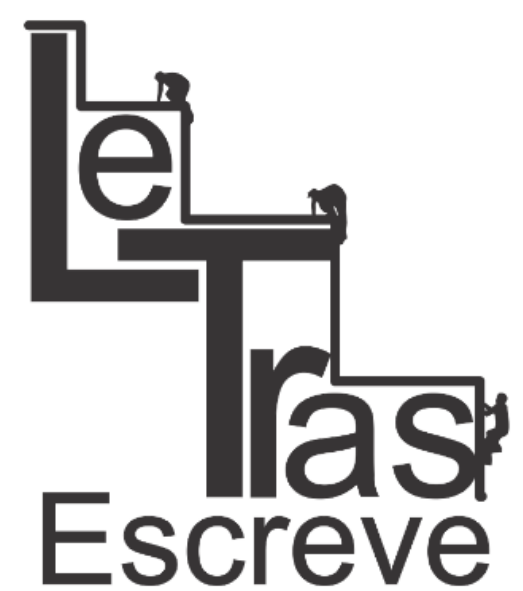

(ISSN 2238-8060)

O encontro das amigas se dá muito tempo depois que as duas se separaram. Sentadas debaixo de árvores no Jardim Botânico, as duas relembram o passado:

Tudo o que, neste momento, lhe parece bombástico e vazio, pois, à voz da amiga, os alegres/angustiosos anos 50/60 renascem desfocados entre as árvores, forçando-a a recomeçar a procura de um fio lógico, a tentar descobrir uma indicação/confirmação dos princípios que a nortearam. Para concluir: o tempo, em lento bombardeio, fez da Cidade uma ruína cuja poeira crestou o rosto das amigas, não haverá recepção em sua volta à cidade destruída, nenhuma coroa ou bandeira, nada de chuva de papel picado (COUTINHO, 1994, p.102, (Amigas (II)).

Ao declarar que não haverá recepção na sua volta, a personagem afirma que não poderá voltar devido à sua transgressão e fuga ao Rio. Por isso, sente-se exilada de tudo e de todos. A única fonte de lembranças é a amiga que a visita no Rio e que, desta vez, Ihe conta um segredo: "na sombra verde entre as árvores, a amiga Ihe contou que tinha um amante" (COUTINHO, 1994, p.103, (Amigas (II)). Casada e com dois filhos crescidos, a amiga conta que não suportou viver presa a um casamento realizado a partir de pressões da família. A personagem que mora no Rio, ao ouvir as lamentações 
da amiga, se dá conta de que nunca mais poderá recuperar as amizades antigas e declara se sentir muito sozinha:

E eu me sinto tão só desde que vim morar aqui, nenhuma amiga de verdade, os homens apenas presenças transitórias. É quando, de repente, revejo num relance a minha vida e tenho, afinal, certeza absoluta de que, se me fosse dado voltar atrás, eu faria tudo exatamente da mesma maneira, outra vez (COUTINHO, 1994, p. 104, (Amigas (II)).

Apesar das dificuldades que vive, a personagem decide que tem uma vida melhor ali e, caso fosse lhe dado uma nova chance faria o mesmo novamente. Para ela, viver em um casamento pelo resto da vida seria a pior das opções. Neste caso, é possível perceber que a personagem, apesar de viver exilada da família, vive melhor do que se estivesse em sua cidade natal, ao não ter de seguir as imposições da família e da cidade provinciana.

\section{Livres, porém solitárias}

Isoladas, exiladas, seja de uma ou de outra forma, estes acontecimentos trouxeram às personagens uma sensação de solidão. Vivendo no Rio, longe de sua cidade natal e de sua família, as personagens, dos três contos, demonstram viver na solidão. Não somente no sentido de saudade da terra natal, como defende Said (2003), mas no sentido de viverem sozinhas, desamparadas e decepcionadas ao descobrir que a liberdade que almejavam não é exatamente o que encontraram, pois aonde quer que vão, ainda encontrarão um mundo dominado pelo sexo masculino. Há também a dificuldade de se relacionar com os outros, aumentando a sensação de solidão das personagens. Vivem, dessa forma, num entre-lugar, ou seja, não se sentem acolhidas na nova morada e também não podem retornar à antiga.

Com origem na prática do banimento, o exilado incorpora o estigma do forasteiro, e, portanto, pertencerá sempre à

https://periodicos.unifap.br/index.php/letras

Macapá, v. 6, n. I, Io semestre, 2016. 


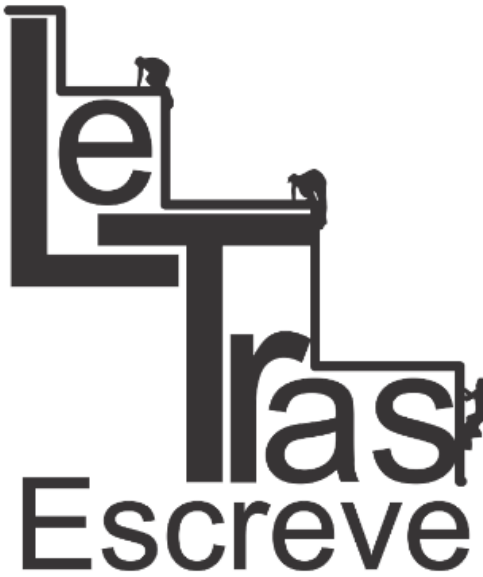

(ISSN 2238-8060)

condição do entre-lugar uma vez que, depois que tenha partido de sua terra natal, não terá mais o mesmo vínculo identitário que o relacionava diretamente àquele lugar. Tampouco se reconhecerá (ou será reconhecido pelos outros) como pertencente ao novo lugar de morada. O estranhamento permanecerá tatuado, como uma cicatriz advinda do deslocamento. Desse modo, por mais que o exilado seja bem sucedido na tarefa de reestruturar-se, ambientalizar-se, organizar sua vida em novas terras, ainda assim se sentirá órfão, noção de pertencer a lugar nenhum (GUILLEN, 2005, apud ZANDONÁ, 2011, p.1)

Como afirma Guillen (2005), o exílio tem origem no banimento, portanto, diante disso, podemos dizer que as personagens foram banidas de suas famílias por não seguirem as normas conservadoras e agora se sentem deslocadas, não pertencentes a lugar nenhum. Zandoná (2011, p.1) acredita que "é nesse ponto que o sentimento de solidão de sobressai", pois, ao não se sentir em casa no novo local, o exilado torna-se deslocado e sente-se órfão, sem pertencimento a lugar nenhum.

O conto em que a solidão pode ser notada com mais clareza e, de fato, está mais presente, é Uma certa felicidade, no qual até mesmo o título traz uma ironia com a felicidade. Ao dizer "Uma certa felicidade", a palavra "certa" denota, neste caso, aquela felicidade almejada, mas que, no final das contas, não é tudo o que a personagem pensava que seria ao mudar para o Rio de Janeiro.

Eu era inquieta, tinha ambições. Pensava em pintar, em levar uma vida livre e independente, coisas que li nos livros e em revistas. Apesar da boa situação econômica em que eu vivia, com minha família, dos planos que fazia com meu noivo, encontrei um homem, apaixonei-me, resolvi largar tudo e vir com ele para o Rio (COUTINHO, 1994, p. 15).

Ao lembrar-se de tudo o que viveu no passado, de quando vivia com os pais e tinha um noivado, planos para o futuro e amigas com quem saía, a personagem descreve a solidão que sente por ter deixado tudo para ir atrás de uma liberdade que não Ihe trouxe a felicidade sonhada.

https://periodicos.unifap.br/index.php/letras

Macapá, v. 6, n. I, Io semestre, 2016. 


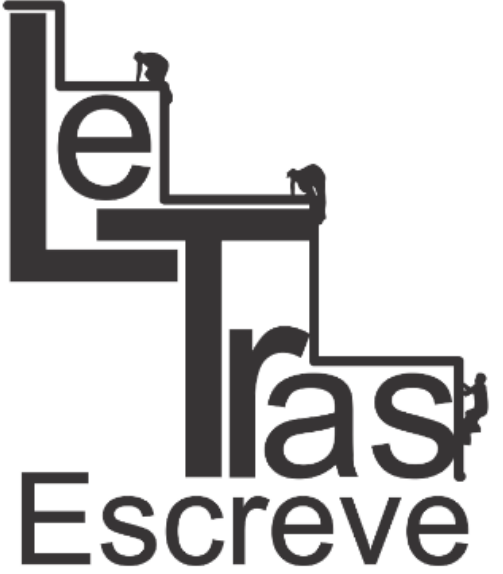

(ISSN 2238-8060)
No fim do dia de trabalho, voltado para casa, em meio ao tráfego terrível das sete, tantas faces desconhecidas e luzes e todo mundo com ar de quem vai chegar para encontrar alguém à espera, enquanto eu abrirei a porta de um apartamento escuro e vazio. Chega então uma espécie de mágoa. Tudo em que pego destruo [...]

Ninguém pode adivinhar o que é isto de se chegar a um apartamento escuro e vazio em Copacabana, no fim de um dia de trabalho. A liberdade inteira. E toda a solidão do mundo. [...] minha liberdade inútil a tiracolo, minha liberdade como uma túnica, como um manto a minha liberdade e solidão [...] (COUTINHO, 1994, p. 50-51).

A solidão relatada pela personagem de Sonia Coutinho revela uma deficiência nas relações interpessoais da personagem, bem como sua insatisfação em ter que viver sozinha e, ao chegar em casa, não ter com quem compartilhar sua vida. Segundo Peplau e Perlman (1982) apud Dornelas (2007), “a definição da solidão remete a uma falha nas relações interpessoais, por considerá-las desagradáveis" (p.262), e "também pode ser compreendida como uma ausência de satisfação nos relacionamentos" (YOUNG, 1982 apud Dornelas, 2007, p. 262). Desta maneira, segundo Dornelas (2007), "a solidão é vista como algo negativo, pois representa um déficit nos relacionamentos em si ou na percepção sobre eles" (p.262).

O sentimento de solidão é tão forte na personagem de Uma certa felicidade, que a mesma decide visitar um amigo, que também veio da cidade baiana e mora no Rio:

Márcia, onde está você? Mas ela chega antes e, muitas vezes, sai logo em seguida. Tenho de ir ver alguém, há este uivar no útero. Um amigo, que sabe como fazer.

Saio do apartamento, caminho de noite pelas calçadas de Copacabana. Quem sabe a porta do prédio dele está fechada, o porteiro pode não querer deixar entrar. Caminho entre muralhas de concreto com minha liberdade inútil a tiracolo, minha liberdade como uma túnica, como um manto a minha liberdade e solidão, chego à porta do edifício, agora, o porteiro parado atrás da mesinha, a luz fluorescente dirigida para o teto, jorrando as sancas, azulejos de mau gosto, lambris ligeiramente estufados como se houvesse uma infiltração descolando-os, por trás (COUTINHO, 1994, p.51). 
O amigo é homossexual e também tem uma vida difícil. Quando os dois sentem-se sozinhos, decidem se encontrar, a fim de amenizar a solidão. Isso fica mais evidente no seguinte fragmento do conto:

- A vida é uma ferida no corpo da morte, ele me disse, certo dia nós dois tão solitários e nem tão jovens assim, e fazendo sexo como alguém que não se ama faz sexo, pior de que tudo, com esta amizade e triste compreensão mútua de quem não mais tão jovem assim, quando ele entrou em orgasmo eu fiquei fria, enquanto ele gritava e dizia nomes ternos eu comecei a chorar, não conseguia aceitar, por mais que quisesse, o que aquele ato esta a me oferecer.

-só com você eu me sinto um homem. Digo isso mesmo sabendo que você não gosta de mim, que só aparece aqui quando se sente sozinha demais, quando não tem outra coisa melhor para fazer. Que vontade de morrer. Como uma roletarussa - à beira de puxar o gatilho, pressentir que a bala está encaixada. [...] Hoje você me deu mais um sursis, ao aparecer por aqui (COUTINHO, 1994, p.54).

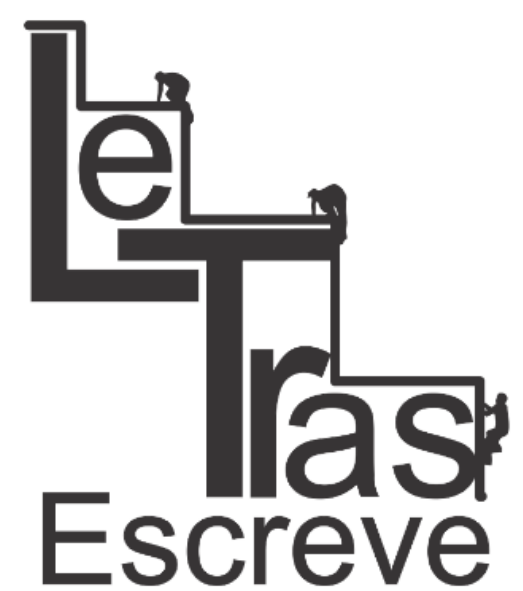

(ISSN 2238-8060)

Enquanto a primeira refere-se ao tempo que as pessoas dispensam à vida social - e com isto resulta em uma menor integração nas redes sociais e um envolvimento superficial das relações -, a solidão emocional apresenta-se como um vazio nas relações interpessoais, o contato com o outro não é significativo (p. 263).

Os dois tipos de solidão são vivenciados pelas personagens aqui apresentadas.

Em Amigas (I) e Amigas (II), há a presença de personagens que se sentem solitárias por terem dificuldades de se relacionar com as outras, como citado anteriormente, o momento em que, a que vive no Rio, recebe a visita da amiga e declara: "finalmente terei com quem falar, só consigo me comunicar de verdade com vocês de lá, o 


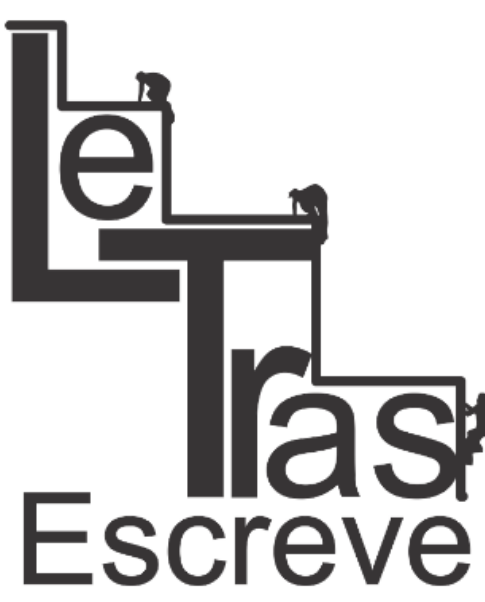

(ISSN 2238-8060)

relacionamento entre as pessoas aqui tão frio e diferente" (COUTINHO, 1994, p.89, Amigas (I)). Portanto, há a dificuldade de se comunicar socialmente, assim como há o desânimo consigo mesma, um sentimento de abandono por não pertencer a lugar nenhum.

Em Amigas (I), há momentos em que a personagem (vivendo no Rio) lembra-se de como era a vivência com sua família: "(Lembro: Pai, Mãe, Irmã, vagas crianças - primos? sobrinhos? - ligando a televisão às seis da tarde, os ruídos da empregada na cozinha, alguém tocando a campainha para "ver como são as coisas", o não estar só...)" (COUTINHO, 1994, p. 89). Também em Amigas (II), há um grande sentimento de solidão que faz parte do cotidiano da personagem principal: "pois durante as noites de insônias ela se esforça para acreditar que existe uma lógica, mesmo que difícil de ser percebida é preciso que haja uma lógica a fim de que ela consiga tornar a dormir" (COUTINHO, 1994, p. 102). Este deslocamento das personagens femininas, impulsionado pelo desejo de liberdade e realização de seus sonhos, aqueles impossíveis em sua cidade natal, Ihes trouxe solidão e sensação de abandono, pois não se sentem em casa em sua nova morada. Trouxe-lhes também a condição de exiladas, pois não podem mais retornar ao seu local de origem.

\section{Considerações Finais}

Há, portanto, nos três contos, o exílio territorial defendido por Said (2003), uma vez que, as personagens não podem retornar à sua terra natal e sentem saudades do seu clima, de suas paisagens.

Exiladas, portanto, estas personagens adquirem uma vida de solidão devido à saudade sentida de sua terra natal e de seus familiares, bem como da companhia de seus antigos amigos e da precária relação com seu novo local de vivência. A sensação de não pertencimento a lugar nenhum agrava ainda mais a sensação de 


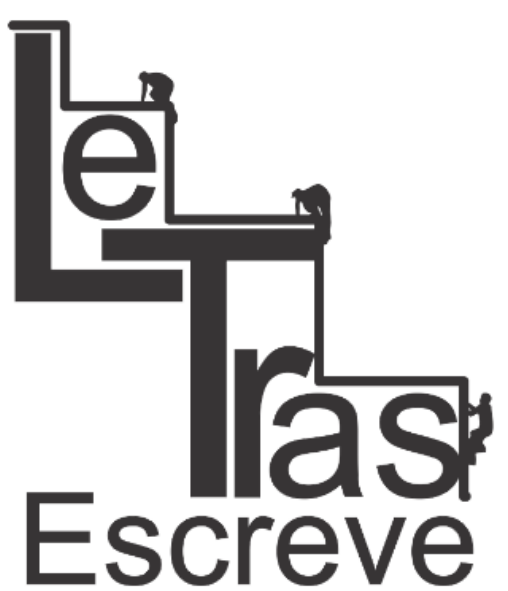

(ISSN 2238-8060)

solidão e, desta forma, as personagens seguem em busca de sua felicidade, de seu lugar na sociedade.

Sonia Coutinho, com sua forma única de narrar o cotidiano de suas personagens, releva o modo de ser na atualidade, onde as mulheres estão em processo de mudança, em transição. Sua linguagem e seu modo de narrar é testemunho desta solidão e exílio com que vivem suas personagens femininas. Quando não são personagens femininas, ou são homossexuais tentando vencer o preconceito ou são poetas masculinos tentando seguir a carreira longe dos pais. O fato de a autora ter vivido em Salvador, na Bahia e ter mudado para o Rio e, em seguida, se divorciado, pode ser visto como um testemunho desta transição e luta para superar as mudanças em uma época de Ditadura Militar. Ao mudar para o Rio, levou consigo suas personagens, já que suas narrativas sempre transitam entre estes dois espaços. Souza (2010) ao falar da teoria de Giorgio Agamben (2008) em O que resta de Auschwitz: o arquivo e o testemunho (Homo Sacer III), afirma que, para Agamben

\begin{abstract}
O testemunho é relegado ao plano da linguagem não como o que resulta da impossibilidade de dizer, mas como um sistema de relação entre o dizível e o indizível; entre o que se pode dizer e aquilo que de fato se diz. É o que fica entre as potencialidades da linguagem e a sua possibilidade efetiva. Dar testemunho é colocar-se nesta cisão entre o que é possível dizer e o que se diz. O testemunho é, assim, uma efetivação possível, uma possibilidade de dizer que carrega a potência do não-dizível (p. 249).
\end{abstract}

Sendo assim, Sonia vivenciou boa parte da transição e testemunha através da linguagem literária o que viveu, utilizando-se de suas personagens. Sua vasta obra inspira mulheres sonhadoras e, ao mesmo tempo, expõe as diversas situações vividas pelas mulheres em uma sociedade conservadora em pleno século XX.

https://periodicos.unifap.br/index.php/letras

Macapá, v. 6, n. I, Io semestre, 2016. 


\section{Referências Bibliográficas}

CESAR, Daisy da Silva. A contística de Sonia Coutinho e suas implicações identitárias. Caderno de Letras da UFF. Dossiê: Preconceito linguístico e cânone literário. $N^{0}$ 36. p.133- 143. 1. sem. 2008.

em:

http://www.uff.br/cadernosdeletrasuff/36/artigo7.pdf Acesso em: 13 dez. 2015

COUTINHO, Sonia. Uma certa felicidade. 2.ed.-Rio de Janeiro: Rocco, 1994. 135p.

DIAS, Gonçalves. Canção do Exílio. Primeiros cantos (1847).

Disponível em: http://www.horizonte.unam.mx/brasil/gdias.html. Acesso em 10 fev. 2016.

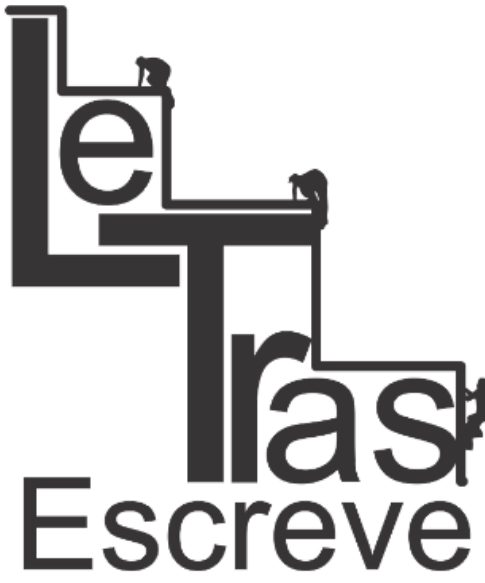

(ISSN 2238-8060)

DORNELAS, Kirlla Cristhine Almeida. A solidão feminina e suas delicadas relações a partir dos romances de Clarice Lispector. Linguagens - Revista de Letras, Artes e Comunicação. Blumenau, v.1, n. 3, p.260, set/dez 2007. Disponível em: http://gorila.furb.br/ojs/index.php/linguagens/article/viewFile/893/808 Acesso em: 13 dez. 2015.

SAID, Edward. Reflexões sobre o exílio. In: Reflexões sobre o exílio e outros ensaios. São Paulo: Companhia das Letras, 2003. P. 46-60.

SANTANA, Patrícia Maria dos Santos. Um estudo das pulsões de vida e morte em Sonia Coutinho. O Guari - Revista eletrônica de literatura - ISSN 1983-6600, 2014. Disponível em: http://oguari.blogspot.com.br/2014/08/um-estudo-das-pulsoes-devida-e-de.html Acesso em: 10 dez. 2015.

SILVA, Lilian Santana da. O corpo na contística de Sonia Coutinho: uma leitura feminista. 2010. Dissertação (mestrado) - Universidade Federal da Bahia, Faculdade de Filosofia e Ciências Humanas. Disponível em: http://www.repositorio.ufba.br/ri/handle/ri/11738 Acesso em: 10 dez. 2015. 
SOUZA, Fábio F. Feltrin de. Resenha: AGAMBEN, Giorgio. O que resta de Auschwitz: o arquivo e o testemunho (Homo Sacer III). São Paulo: Boitempo Editorial, 2008, 175 p. Tempo e Argumento Revista do Programa de Pós-Graduação em História. Florianópolis, v. 2, n. 1, p. 247 - 250, jan./jun. 2010. Disponível em: http://www.revistas.udesc.br/index.php/tempo/article/viewFile/1941/1 $\underline{543}$ Acesso em:_23 jan 2016.

ZANDONÁ, Jair. A casa dos exílios ou os olhos nublados da solidão. In: XII Congresso Internacional da ABRALIC (UFPR), 2011, Curitiba. Anais Online. Curitiba: UFPR, 2011. Disponível em: http://www.abralic.org.br/eventos/cong2011/AnaisOnline/resumos/TC 0966-1.pdf Acesso em: 10 fev. 2016.

Recebido em 31/07/2016. Aprovado em 17/08/2016.

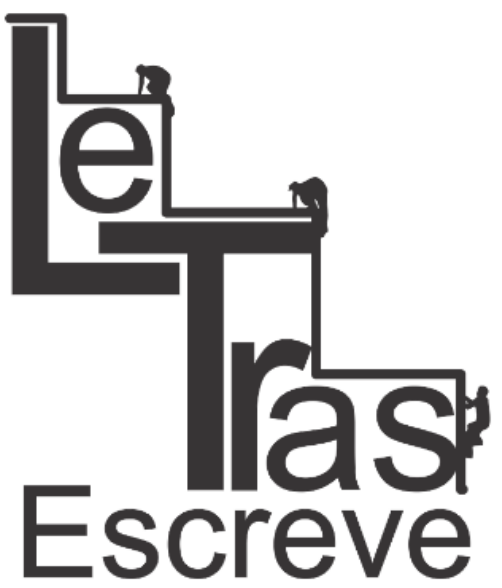

(ISSN 2238-8060) 